\title{
Kinerja Slow Sand Filter dengan Bantuan Lampu Light-Emitting Diode (LED) Biru dan Merah
}

\author{
Vanny Widiyanti dan Wahyono Hadi \\ Departemen Teknik Lingkungan, Fakultas Teknik Sipil, Lingkungan, dan Kebumian, Institut Teknologi \\ Sepuluh Nopember (ITS) \\ e-mail:wahyono@enviro.its.ac.id
}

\begin{abstract}
Abstrak-Kebutuhan air bersih yang semakin besar terutama pada wilayah perkotaan yang minim sumber daya air mengakibatkan kebutuhan persediaan air bersih bagi masyarakat meningkat. Selain masalah kualitas air masalah yang muncul saat ini adalah terbatasnya lahan untuk pengolahan air untuk mengatasi permasalahan mengenai pengolahan air tersebut maka digunakan sistem pengolahan air minum dengan menggun slow sand filter (SSF) dengan bantuan lampu light-emitting diode (LED) Biru dan Merah sebagai cahaya dalam proses SSF. Dalam penelitian yang bertujuan untuk menentukan kontribusi dari penggunaan lampu LED biru dan merah ini dilakukan tahapan yaitu tahap analisis awal, tahap aklimatisasi dan tahap pengoperasian dengan tiga variasi kecepatan yaitu $0,1 \mathrm{~m}^{3} / \mathrm{m}^{2}$.jam, dan $0,3 \mathrm{~m}^{3} / \mathrm{m}^{2}$.jam, serta dilakukan analisis parameter uji kekeruhan, zat organik, dan total coliform. Hasil penelitian menunjukkan bahwa penggunaan SSF dengan bantuan lampu LED biru dan merah terhadap parameter kekeruhan memiliki efisiensi sebesar 84,45\%-95,49\% dengan kontribusi penggunaan lampu LED sebesar $1,28 \%-11,98 \%$, dan pada parameter uji zat organik nilai efisiensi sebesar $81,67 \%-91,91 \%$ dengan ekontribusi penggunaan lampu LED biru dan merah sebesar 42,71\%$\mathbf{7 5 , 3 6 \%}$, dan pada parameter total coliform efisiensi removal sebesar 92,89\%-99,37\% dengan kontribusi dari penggunaan lampu sebesar 2,86\%-12,23\%. Berdasarkan hasil penelitian didapatkan bahwa penggunaan lampu LED berwarna merah dengan kecepatan laju filtrasi $0,1 \mathrm{~m}^{3} / \mathrm{m}^{2}$.jam memiliki rata-rata efisiensi removal paling optimal.
\end{abstract}

Kata Kunci-Coliform, Geotextile, LED Biru, LED Merah, slow sand filter

\section{PENDAHULUAN}

$\mathrm{K}$ EBUTUHAN air bersih yang semakin besar bagi masyarakat meningkat, kemudian adanya penggunaan air sumur yang masih digunakan sebagai air baku untuk pemenuhan sehari-hari oleh masyarakat. Diperlukan adanya pengolahan air untuk memenuhi kualitas baku mutu air bersih sesuai dengan Peraturan Menteri Kesehatan Republik Indonesia Nomor 492/MENKES/PER/IV/2010 tentang Persyaratan Kualitas Air Minum dilakukan pengolahan air dengan menggun unit filtrasi.

Dalam Penelitian ini unit yang digunakan adalah slow sand filter (SSF) yang memiliki kelebihan tidak diperlukannya bahan kimia dalam prosesnya serta memiliki efisiensi penurunan yang tinggi [1]. Adapun kekurangan dari penggunaan SSF ini adalah membutuhkan lahan yang luas, oleh sebab itu dalam penelitian ini diharapkan SSF dapat digunakan dalam ruang ataupun dalam gedung bertingkat. Dikaren SSF membutuhkan cahaya dalam pembentukan lapisan biofilm [2] maka dalam penelitian ini digunakan lampu Light-Emitting Diode (LED) sebagai cahaya dalam proses SSF di dalam ruangan. Penggunaan LED biru dan merah dikaren lampu LED biru memiliki panjang gelombang sebesar 450-500 nm dan LED merah sebesar 610-760 nm. Warna merah dan biru dipilih karena gelombang LED berwarna merah dan biru baik untuk pertumbuhan dikaren klorofil menyerap cahaya ini sehingga proses fotosintesis dapat berjalan dengan optimal [3]. Pada proses SSF di dalam penelitian ini lampu LED mempengaruhi pertumbuhan lapisan schmutzdecke dalam SSF, lapisan schmutzdecke yang mengandung bakteri, protozoa, fungi, larva serangga air, rotivera [4] merup proses utama dalam unit SSF dan proses yang berjalan pada SSF adalah proses mechanical straining dan adsorpsi, proses mechanical straining merup sebuah proses penyaringan partikel yang lebih besar dari porositas media. Proses ini terjadi pada permukaan filter dan proses adsorpsi yaitu proses absorbsi partikel koloid yang bermuatan positif oleh media pasir kwarsa yang bermuatan negatif. Proses ini dapat menghilangkan partikel koloid yang berasal dari bahan-bahan organik maupun non-organik yang tidak terendapkan [1]. Dalam menenttukan besar kontribusi dari penggunaan lampu LED biru dan merah ini SSF dioperasikan dalam tiga variasi laju kecepatan yaitu $0,1 \mathrm{~m}^{3} / \mathrm{m}^{2} / \mathrm{jam}$, dan 0,3 $\mathrm{m}^{3} / \mathrm{m}^{2} / \mathrm{jam}$. kemudian dilakukan analisis pada masing-masing outlet reaktor dengan parameter uji kekeruhan, zat organik, dan total coliform. Slow sand filter dioperasikan dengan aliran downflow.

\section{Metode Penelitian}

\section{A. Tahap Analisis Awal}

Penelitian pendahuluan bertujuan untuk menentukan sumber air baku yang digunakan dalam pengolahan menggun downflow slow sand filter. Air baku yang dipilih adalah air sumur Kecamatan Mulyorejo Surabaya. Penelitian 
pendahuluan ini dilakukan dengan menganalisis parameter fisik, kimia, serta biologis dalam air yaitu kekeruhan, zat organik, dan total coliform

Pada penelitian pendahuluan ini dilakukan juga analisis awal intensitas cahaya dari lampu LED biru dan LED merah. Sehingga dapat dibandingkan intensitas cahaya lampu dari masing-masing warna tersebut terhadap air yang digunakanakan.

\section{B. Tahap Aklimatisasi}

Pada tahap aklimatisasi 4 reaktor yang terdiri dari 2 reaktor kontrol di dalam ruangan dan di luar ruangan, serta 2 reaktor lainnya yang terdapat LED biru dan merah dialiri air baku setiap harinya selama 14 hari. Pada tahap aklimatisasi ini laju filtrasi yang digunakanakan yaitu $0,3 \mathrm{~m}^{3} / \mathrm{m}^{2} / \mathrm{jam}$. Media Geotextile dan pasir diaklimatisasi menggun air baku yang berasal dari sumber air baku yaitu air sumur. Aklimatisasi dilakukan dengan mengoperasikan reaktor slow sand filter setiap hari selama masa aklimatisasi (14 hari) dan air baku tersebut diganti setiap harinya. Perendaman media dalam air baku berlangsung selama 14 hari karena diperkir media sudah ditumbuhi oleh lapisan biofilm.

\section{Tahap pengoperasian}

Pengoperasian dilakukan selama 5 hari dengan menggun laju filtrasi $0,3 \mathrm{~m}^{3} / \mathrm{m}^{2}$. Jam kemudian 5 hari dengan $0,2 \mathrm{~m}^{3} / \mathrm{m}^{2}$. Jam, dan 5 hari dengan laju filtrasi $0,1 \mathrm{~m}^{3} / \mathrm{m}^{2}$.jam. Pengaturan kecepatan dilakukan dengan cara melakukan running selama 1 menit lalu dianalisis jumlah debit yang dihasilkan. Kemudian dilakukan perhitungan untuk mengetahui laju filtrasi yang terjadi, dilakukan terus menerus hingga mendapatkan laju yang dinginkan. Pengoperasian dilakukan dengan aliran downflow. Pada tahap ini dioperasikan semua reaktor baik yang menggun sinar matahari dan dengan reaktor yang menggun lampu LED. Reaktor bekerja secara kontinyu selama 24 jam

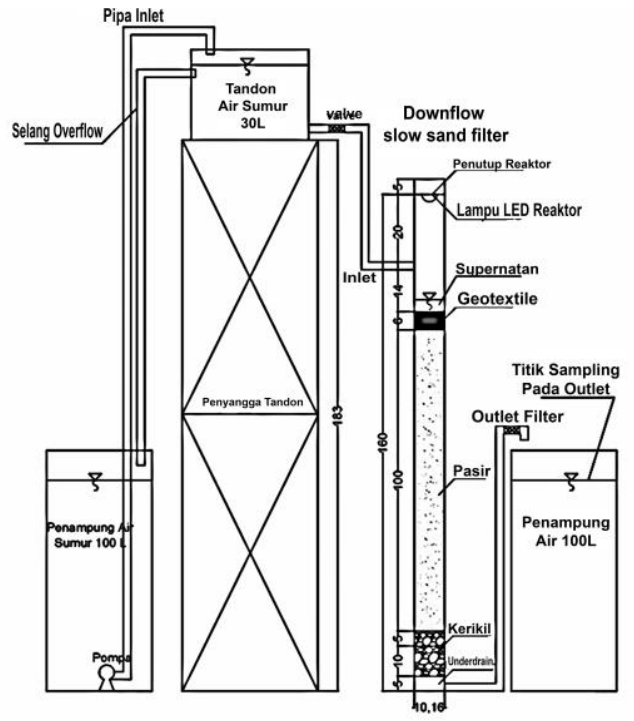

Gambar 1. Reaktor downflow slow sand filter

Total titik sampling yang dianalisis pada penelitian ini sebanyak 5 titik sampling, dimana satu titik sampling diambil pada bagian inlet dari air baku yang di sampling dan diambil satu titik sampling pada outlet masing-masing reaktor. Pengambilan sampel dilakukan setiap harinya pada pagi hari dan dalam satu hari hanya dilakukan sekali sampling. Setelah melakukan sampling, selanjutnya sampel air dianalis is sesuai dengan parameter penelitian kekeruhan, zat organik, dan total coliform.

\section{ANALISIS DAN PEMBAHASAN}

\section{A. Tahap analisis awal}

Pada tahap analis is awal air baku yang berasal dari air sumur Kecamatan Mulyorejo Surabaya dilakukan analasis pada setiap parameter. Pada parameter kekeruhan dilakukan analisis dengan metode turbidimetri sehingga didapatkan nilai kekeruhan sebesar 8,43 NTU. Kemudian pada parameter zat organik dilakukan analisis dengan menggun uji nilai permanganat sehingga didapatkan kandungan zat organik di dalam air baku tersebut sebesar $29,07 \mathrm{mg} / \mathrm{L}$, dan pada parameter total coliform didapatkan kandungan total coliform sebanyak 16000/100 mL s ampel pada air baku.

\section{B. Tahap aklimatisasi}

Pada tahap aklimatisasi reaktor SSF dijalankan selama 14 hari dikaren pembentukan schmutzdecke membutuhkan waktu 2-3 minggu [5], pengoperasian SSF selama tahap aklimatisasi dilakukan dengan mengaliri reaktor yang berisi media geotekstil maupun pasir secara kontinyu.

Pada tahap aklimatisasi pengambilan sampel dilakukan pada awal aklimatisasi dan akhir aklimatisasi sehingga didapatkan hasil Analisa sampel pada setiap parameter. Pada parameter kekeruhan didapatkan nilai inlet yang masuk pada awal aklimatisasi adalah sebesar 5,48 NTU dan nilai kekeruhan terendah sebesar 0,78 NTU sehingga efisiensi filter tertinggi sebesar $85,77 \%$. Kemudian pada akhir aklimatisasi didapatkan dengan nilai inlet sebesar 6,53 NTU kekeruhan terendah pada reaktor dengan menggun lampu LED merah yaitu sebesar 0,57 NTU dengan nilai efisiensi removal sebesar 88,06\%. Adanya penurunan kekeruhan pada akhir aklimatisasi disebabkan adanya proses fisik dalam SSF yaitu mechanical straining yang berperan dalam menyisihkan serta menyaring bahan pencemar pada rongga antar butiran yang lebih kecil dari ukuran partikel pencemar [6].

Pada parameter zat organik jumlah kandungan zat organik pada inlet sebesar 42,19 mg/L kemudian didapatkan pada awal aklimatis asi nilai outlet terendah sebesar 22,59 mg/L. kemudian pada akhir aklimatis asi didapatkan nilai inlet sebes ar 24,02 mg/L dengan nilai outlet terendah sebesar $6,32 \mathrm{mg} / \mathrm{L}$. sehingga ratarata efisiensi removal tertinggi terhadap parameter zat organik adalah sebesar $60,07 \%$.

Dalam menurunkan parameter total coliform pada awal aklimatisasi didapatkann nilai inlet sebesar 13000/100 mL sampel dengan nilai outlet terendah sebesar 2100/100 mL sampel. Kemudian pada akhir aklimatisasi dengan nilai inlet 700/100 mL sampel nilai outlet terendah sebesarr 280/100 mL sampel. 


\section{Tahap pengoperasian}

Pada tahap pengoperasian dilakukan dengan menggun laju filtrasi $0,3 \mathrm{~m}^{3} / \mathrm{m}^{2}$.jam selama 5 hari, kemudian dilanjutkan dengan kecepatan filtrasi $0,2 \mathrm{~m}^{3} / \mathrm{m}^{2}$.jam selama 5 hari pengoperasian, dan dengan laju filtrasi $0,1 \mathrm{~m}^{3} / \mathrm{m}^{2}$.jam selama 5 hari. Pada awal pengoperasian $0,3 \mathrm{~m}^{3} / \mathrm{m}^{2}$.jam debit yang dialirkan pada reaktor SSF adalah sebesar 40,5 mL/menit. Serta pada kecepatan $0,1 \mathrm{~m}^{3} / \mathrm{m}^{2}$.jam debit yang memasuki reaktor SSF sebesar 13,5 $\mathrm{mL}$ menit. Perhitungan debit yang masuk dilakukan secara manual dengan menggun bekker glass yang dialiri air dengan waktu selama 1 menit. Kemudian didapatkan hasil dari masing-masing parameter uji pada keempat reaktor dalam ketiga variasi kecepatan.

- Pengaruh penggunaan lampu LED dalam SSF pada kecepatan laju filtrasi $0,3 \mathrm{~m}^{3} / \mathrm{m}^{2} . j a m$

Berikut adalah hasil analisis parameter kekeruhan pada outlet masing-masing reaktor dengan 5 titik sampling pada kecepatan filtrasi $0,3 \mathrm{~m}^{3} / \mathrm{m}^{2}$.jam

$$
\text { Tabel } 1 .
$$

Hasil Analisis Kekeruhan pada Reaktor SSF dengan Laju Filtrasi 0,3

\begin{tabular}{|c|c|c|c|c|c|}
\hline \multirow[b]{2}{*}{$\begin{array}{l}\text { Hari } \\
\text { ke - }\end{array}$} & \multirow[b]{2}{*}{$\begin{array}{l}\text { Kekeruhan } \\
\text { Inlet } \\
\text { (NTU) }\end{array}$} & \multicolumn{4}{|c|}{ Kekeruhan Outlet } \\
\hline & & $\begin{array}{c}\text { Kontrol } \\
\text { Luar } \\
\text { (NTU) }\end{array}$ & $\begin{array}{c}\text { Kontrol } \\
\text { Dalam } \\
(\mathrm{NTU})\end{array}$ & $\begin{array}{c}\text { LED } \\
\text { Merah } \\
\text { (NTU) } \\
\end{array}$ & $\begin{array}{c}\text { LED } \\
\text { Biru } \\
(\mathrm{NTU}) \\
\end{array}$ \\
\hline 1 & 5,55 & 0,87 & 0,65 & 0,54 & 0,54 \\
\hline 2 & 3,13 & 1,47 & 1,36 & 0,74 & 1,28 \\
\hline 3 & 5,67 & 1,07 & 0,75 & 0,52 & 0,52 \\
\hline 4 & 3,67 & 1,12 & 0,51 & 0,54 & 0,39 \\
\hline 5 & 7,2 & 0,85 & 0,61 & 0,48 & 0,53 \\
\hline
\end{tabular}

Pada parameter kekeruhan dengan kecepatan $0,3 \mathrm{~m}^{3} / \mathrm{m}^{2} . j a m$ didapatkan bahwa selama pengoperasian nilai kekeruhan terendah sebesar 0,48 NTU dengan nilai rata-rata efisiensi removal sebesar $87,22 \%$. Setelah diketahui nilai kekeruhan masing-masing outlet, maka pengaruh dari penggunaan lampu LED dapat diketahui. Besarnya pengaruh dari penggunaan lampu LED didapatkan dengan menghitung selisih dari nilai kekeruhan yang terdapat pada lampu LED merah/biru dengan reaktor kontrol dalam suatu ruangan yang sama. Sehingga didapatkan besar pengaruh penggunaan lampu LED merah adalah 5,37\% dan pada LED biru sebesar 2,59\%. Kemudian dilakukan analisis terhadap parameter zat organik di masingmasing reaktor.

Kemudian dilakukan analisis Kandungan zat organik terlihat pada Tabel 2

Tabel 2.

Hasil Analisis Zat Organik pada Reaktor SSF dengan Laju Filtrasi 0,3 $\mathrm{m}^{3} / \mathrm{m}^{2} . \mathrm{jam}$

\begin{tabular}{|c|c|c|c|c|c|}
\hline \multirow[b]{2}{*}{$\begin{array}{l}\text { Hari } \\
\text { ke - }\end{array}$} & \multirow{2}{*}{$\begin{array}{c}\text { Zat } \\
\text { Organik } \\
\text { Inlet } \\
(\mathrm{mg} / \mathrm{L})\end{array}$} & \multicolumn{4}{|c|}{ Zat Organik Outlet } \\
\hline & & $\begin{array}{c}\text { Kontrol } \\
\text { Luar } \\
(\mathrm{mg} / \mathrm{L})\end{array}$ & $\begin{array}{l}\text { Kontrol } \\
\text { Dalam } \\
(\mathrm{mg} / \mathrm{L})\end{array}$ & $\begin{array}{c}\text { LED } \\
\text { Merah } \\
(\mathrm{mg} / \mathrm{L})\end{array}$ & $\begin{array}{c}\text { LED Biru } \\
(\mathrm{mg} / \mathrm{L})\end{array}$ \\
\hline 1 & 27,81 & 25,28 & 19,59 & 2,53 & 4,47 \\
\hline 2 & 23,51 & 23,00 & 20,65 & 8,22 & 6,32 \\
\hline 3 & 23,51 & 20,86 & 16,43 & 2,65 & 4,30 \\
\hline 4 & 25,53 & 20,60 & 16,68 & 0,63 & 3,16 \\
\hline 5 & 23,13 & 18,96 & 16,43 & 1,26 & 4,17 \\
\hline
\end{tabular}

Pada parameter zat organik analisis dilakukan dengan metode uji nilai permanganat sehingga didapatkan nilai ratarata efisiensi removal sebesar $87,36 \%$ dengan nilai kekeruhan terendah selama pengoperasian sebesar $0,63 \mathrm{mg} / \mathrm{L}$. Kemudian didapatkan kontribusi dari penggunaan lampu LED pada reaktor SSF dengan menghitung selisih antara reaktor SSF dengan menggun lampu LED merah/biru dengan reaktor kontrol dalam suatu ruangan yang sama, sehingga didapatkan kontribusi penggunaan lampu LED merah dalam reaktor SSF adalah sebesar $60,27 \%$ dan kontribusi dari penggunaan lampu LED biru pada reaktor SSF adalah sebesar 54,58\%.

Setelah dilakukan analisis pada parameter zat organik dilanjutkan pada parameter uji total coliform. berikut hasil analisis parameter total coliform pada Tabel 3

Tabel 3.

Hasil Analisis Total Coliform pada Reaktor SSF dengan Laju Filtrasi 0,3 $\mathrm{m}^{3} / \mathrm{m}^{2} . \mathrm{jam}$

\begin{tabular}{cccccc}
\hline \hline & & \multicolumn{4}{c}{ Total coliform Outlet } \\
\cline { 3 - 6 } Hari & Coliform & Kontrol & Kontrol & LED & LED \\
$\mathrm{ke}-$ & Inlet & Luar & Dalam & Merah & Biru \\
& $(/ 100 \mathrm{~mL}$ & $(/ 100$ & $(/ 100$ & $(/ 100$ & $(/ 100$ \\
& sampel $)$ & $\mathrm{mL}$ & $\mathrm{mL}$ & $\mathrm{mL}$ & $\mathrm{mL}$ \\
& & sampel $)$ & sampel $)$ & sampel $)$ & sampel $)$ \\
\hline 1 & 1600 & 610 & 430 & 210 & 270 \\
2 & 1300 & 300 & 310 & 135 & 113 \\
3 & 1600 & 280 & 320 & 64 & 90 \\
4 & 2800 & 260 & 240 & 42 & 85 \\
5 & 3100 & 250 & 210 & 27 & 41 \\
\hline \hline
\end{tabular}

Dilanjutkan analisis sampel pada parameter total coliform pada Tabel 3. Pada kelima hari pengoperasian SSF pada parameter total coliform didapatkan efisiensi filter mengalami peningkatan setiap harinya, sehingga didapatkan nilai rata-rata efisiensi tertinggi sebesar 94,03\% Pada pengoperasian SSF hasil outlet masih belum stabil hal ini dikaren mikroorganisme dalam lapisan schmutzdecke masih dalam proses pertumbuhan pada fase-2 yaitu fase logaritmik [6].

- Pengaruh penggunaan lampu LED berwarna dalam reaktor SSF pada kecepatan laju filtrasi $0,1 \mathrm{~m}^{3} / \mathrm{m}^{2}$.jam

Setelah dilakukan pengoperasian dengan laju filtrasi 0,3 $\mathrm{m}^{3} / \mathrm{m}^{2}$.jam dilanjutkan dengan pengoperasian dengan menggun laju filtrasi $0,1 \mathrm{~m}^{3} / \mathrm{m}^{2}$. Jam dengan waktu pengoperasian selama 5 hari dengan debit aliran yang masuk sebesar $13,5 \mathrm{~mL} /$ menit. Kemudian dilakukan analisis dari outlet masing-masing reaktor terhadap parameter kekeruhan terlihat pada Tabel 4

Tabel 4.

Hasil Analisis Kekeruhan pada Reaktor SSF dengan Laju Filtrasi 0,1 $\mathrm{m}^{3} / \mathrm{m}^{2} . \mathrm{jam}$

\begin{tabular}{cccccc}
\hline \hline & & \multicolumn{4}{c}{ Kekeruhan Outlet } \\
\cline { 3 - 6 } $\begin{array}{c}\text { Hari } \\
\text { ke }-\end{array}$ & $\begin{array}{c}\text { Kekeruhan } \\
\text { Inlet } \\
\text { (NTU) }\end{array}$ & $\begin{array}{c}\text { Kontrol } \\
\text { Luar } \\
(\mathrm{NTU})\end{array}$ & $\begin{array}{c}\text { Kontrol } \\
\text { Dalam } \\
(\mathrm{NTU})\end{array}$ & $\begin{array}{c}\text { LED } \\
\text { Merah } \\
(\mathrm{NTU})\end{array}$ & $\begin{array}{c}\text { LED } \\
\text { Biru } \\
(\mathrm{NTU})\end{array}$ \\
\hline 1 & 11 & 1,3 & 0,7 & 0,6 & 0,6 \\
2 & 11 & 1,2 & 0,7 & 0,5 & 0,55 \\
3 & 10 & 1 & 0,6 & 0,43 & 0,48 \\
4 & 13 & 0,98 & 0,75 & 0,52 & 0,57 \\
5 & 14 & 1,33 & 0,88 & 0,6 & 0,66 \\
\hline \hline
\end{tabular}


Pada Tabel 4 terlihat bahwa dalam parameter kekeruhan dengan kecepatan $0,1 \mathrm{~m}^{3} / \mathrm{m}^{2}$. Jam didapatkan nilai kekeruhan terendah sebesar 0,43 NTU yang didapatkan dalam reaktor SSF dengan menggun lampu LED merah, dengan nilai inlet yang masuk pada hari tersebut adalah 10 NTU. Sehingga rata-rata efisiensi filter pada parameter kekeruhan adalah sebesar $95,49 \%$

Setelah didapatkan nilai kekeruhan pada masing-masing outlet reaktor, kemudian dihitung besar kontribusi penggunaan lampu LED merah dan biru di dalam reaktor SSF. Perhitungan dilakukan dengan cara selisih antara reaktor dengan menggun lampu LED dengan reaktor kontrol tanpa menggun LED di dalam suatu ruangan yang sama. Didapatkan besar kontribusi penggunaan lampu LED merah pada kecepatan $0,1 \mathrm{~m}^{3} / \mathrm{m}^{2}$.jam adalah sebesar $1,64 \%$ dan pada penggunaan lampu LED biru sebesar $1,28 \%$. Kemudian dilanjutkan analisis pada parameter zat organik yang terdapat pada Tabel 5 .

Tabel 5.

Hasil Analisis Zat Organik pada reaktor SSF dengan Laju Filtrasi 0,1 $\mathrm{m}^{3} / \mathrm{m}^{2} . \mathrm{jam}$

\begin{tabular}{|c|c|c|c|c|c|}
\hline \multirow[b]{2}{*}{$\begin{array}{l}\text { Hari } \\
\text { ke - }\end{array}$} & \multirow[b]{2}{*}{$\begin{array}{c}\text { Zat } \\
\text { Organik } \\
\text { Inlet } \\
(\mathrm{mg} / \mathrm{L})\end{array}$} & \multicolumn{4}{|c|}{ Zat Organik Outlet } \\
\hline & & $\begin{array}{l}\text { Kontrol } \\
\text { Luar } \\
(\mathrm{mg} / \mathrm{L})\end{array}$ & $\begin{array}{c}\text { Kontrol } \\
\text { Dalam } \\
(\mathrm{mg} / \mathrm{L})\end{array}$ & $\begin{array}{l}\text { LED } \\
\text { Merah } \\
(\mathrm{mg} / \mathrm{L})\end{array}$ & $\begin{array}{c}\text { LED } \\
\text { Biru } \\
(\mathrm{mg} / \mathrm{L})\end{array}$ \\
\hline 1 & 37,15 & 29,94 & 24,84 & 3,67 & 4,87 \\
\hline 2 & 35,19 & 26,19 & 20,94 & 2,47 & 3,52 \\
\hline 3 & 32,94 & 23,49 & 16,43 & 1,57 & 2,47 \\
\hline 4 & 35,04 & 22,44 & 13,43 & 1,87 & 3,67 \\
\hline 5 & 28,44 & 23,04 & 16,43 & 3,82 & 5,02 \\
\hline
\end{tabular}

Pada parameter zat organik didapatkan hasil analisis rata-rata efisiensi tertinggi yaitu sebesar $91,91 \%$ dengan kandungan zat organik terndah sebesar 1,57 mg/L. Kandungan zat organik minimum didapatkan pada hari ke-3 pengoperasian SSF dengan menggun reaktor SSF menggun lampu LED merah. Besar kontribusi yang didapatkan dari pengaruh penggunaan lampu LED merah adalah sebesar 46,37\% dan kontribusi dari penggunaan lampu LED biru adalah sebesar $42,71 \%$. Kemudian dilakukan analisis pada parameter berikutnya yaitu parameter total coliform sehingga didapatkan jumlah kandungan total coliform selama kelima hari pengoperasiand dengan kecepatan $0,1 \mathrm{~m}^{3} / \mathrm{m}^{2}$.jam selama lima hari pengoperasian didapatkan pada Tabel 6.

Tabel 6.

Hasil Analisis Total Coliform pada Reaktor SSF dengan Laju Filtrasi 0,1 $\mathrm{m}^{3} / \mathrm{m}^{2} . \mathrm{jam}$

\begin{tabular}{|c|c|c|c|c|c|}
\hline \multirow[b]{2}{*}{$\begin{array}{l}\text { Hari } \\
\text { ke - }\end{array}$} & \multirow[b]{2}{*}{$\begin{array}{c}\text { Total } \\
\text { coliform } \\
\text { Inlet } \\
\text { (/100 mL } \\
\text { sampel) }\end{array}$} & \multicolumn{4}{|c|}{ Total Coliform Outlet } \\
\hline & & $\begin{array}{l}\text { Kontrol } \\
\text { Luar } \\
\text { (/100 mL } \\
\text { sampel) }\end{array}$ & $\begin{array}{c}\text { Kontrol } \\
\text { Dalam } \\
\text { (/100 } \\
\text { mL } \\
\text { sampel) } \\
\end{array}$ & $\begin{array}{l}\text { LED } \\
\text { Merah } \\
\text { (/100 mL } \\
\text { sampel) }\end{array}$ & $\begin{array}{c}\text { LED } \\
\text { Biru } \\
(/ 100 \\
\text { mL } \\
\text { sampel }) \\
\end{array}$ \\
\hline 1 & 4100 & 260 & 160 & 7 & 6 \\
\hline 2 & 2800 & 190 & 110 & 3 & 4 \\
\hline 3 & 2600 & 210 & 120 & 2 & 9 \\
\hline 4 & 2600 & 220 & 130 & 8 & 13 \\
\hline 5 & 2400 & 210 & 130 & 17 & 21 \\
\hline
\end{tabular}

Nilai terendah sebesar $2 / 100 \mathrm{~mL}$ sampel dengan nilai inlet pada hari tersebut adalah sebesar 2600/ $100 \mathrm{~mL}$ sampel sehingga nilai efisiensi filter tertinggi sebesar 99,93\%. Kemudian dilakukan perhitungan besar kontribusi dari pemakaian reaktor SSF dengan menggun lampu LED merah dan biru terhadap reaktor tanpa menggun lampu. Besar kontribusi penggunaan lampu LED berwarna merah didapatkan yaitu 4,30\% dan 4,17\% pada penambahan lampu LED biru.

Kemudian dari pengoperasian berdasarkan variasi laju filtrasi didapatkan rata-rata efisiensi penurunan filter pada masing-masing reaktor terdapat dalam Tabel 7.

Tabel 7.

Rata-rata Efisiensi Removal Slow Sand Filter

\begin{tabular}{|c|c|c|c|c|}
\hline \multirow{3}{*}{ Parameter } & \multicolumn{4}{|c|}{ Efisiensi removal filter (\%) } \\
\hline & \multicolumn{2}{|c|}{ Kontrol Luar } & \multicolumn{2}{|c|}{ Kontrol Dalam } \\
\hline & 1 & 2 & 1 & 2 \\
\hline Kekeruhan & 75,24 & 90,05 & 81,85 & 93,85 \\
\hline Zat organik & 11,98 & 25,74 & 27,09 & 45,54 \\
\hline \multirow[t]{2}{*}{ Total Coliform } & 80,79 & 92,32 & 82,79 & 95,43 \\
\hline & \multicolumn{4}{|c|}{ Efisiensi removal filter $(\%)$} \\
\hline \multirow[t]{2}{*}{ Parameter } & \multicolumn{2}{|c|}{ LED merah } & \multicolumn{2}{|c|}{ LED biru } \\
\hline & 1 & 2 & 1 & 2 \\
\hline Kekeruhan & 87,22 & 95,49 & 84,45 & 95,13 \\
\hline Zat organik & 87,36 & 91,91 & 81,67 & 88,25 \\
\hline Total Coliform & 94,03 & 99,73 & 92,89 & 99,60 \\
\hline
\end{tabular}

Pada ketiga parameter diatas terlihat bahwa pada masingmasing reaktor di setiap parameter memiliki efisiensi removal tertinggi pada kecepatan filtrasi $0,1 \mathrm{~m}^{3} / \mathrm{m}^{2}$.jam terlihat pada tabel 7.

\section{KESIMPULAN}

1. Kinerja slow sand filter dengan bantuan lampu LED biru dan merah pada pengoperasian laju fitrasi $0,1 \mathrm{~m}^{3} / \mathrm{m}^{2}$.jam, dan $0,3 \mathrm{~m}^{3} / \mathrm{m}^{2}$.jam menghasilkan efisiensi sebagai berikut:

- Pada parameter kekeruhan reaktor dengan menggun lampu LED merah dan biru memiliki rata efisiensi removal sebesar 59,11\%-96,22\%

- Pada parameter zat organik reaktor dengan menggun lampu LED merah dan biru memiliki efisiensi removal sebesar $65,06 \%-99,34 \%$

- Pada parameter total coliform reaktor dengan menggun lampu LED merah dan biru memiliki efisiensi removal sebesar $83,13 \%$ hingga $99,93 \%$

2. Kontribusi dari lampu LED biru didapatkan pada parameter kekeruhan sebesar 0,91\%-3,53\%, kemudian pada penurunan efisiensi zat organik sebesar 19,8\%-60,96\%, dan pada parameter total coliform kontribusi dari penggunaan lampu LED biru adalah 1,52\%-15,15\%. Penggunaan lampu LED merah di dalam reaktor SSF memiliki kontribusi sebesar 1,81\%-5,06\% pada parameter kekeruhan, kemudian pada parameter zat organik sebesar 27,22-65,59\%, dan pada 
parameter total coliform lampu LED merah memiliki kontribusi sebesar $1,76 \%-16 \%$.

3. Pada pengoperasian SSF menggun bantuan lampu LED merah dan biru didapatkan reaktor SSF dengan menggun lampu LED merah lebih baik dibandingkan dengan reaktor SSF dengan menggun bantuan lampu LED berwarna biru, dengan menggun variasi laju filtrasi $0,1 \mathrm{~m}^{3} / \mathrm{m}^{2}$.jam.

\section{DAFTAR PUSTAKA}

[1] Al-Layla M.A, Ahmad S., Middlebrooks J.E., 1978, Water Supply Engineering Design. Michigan: Ann Arbor Science Publishers Inc.W.-K. Chen, Linear Networks and Systems (Book style). Belmont, CA: Wadsworth (1993) 123-135.

[2] Huisman, L. and Wood, W.E. .1974. Slow Sand Filtration. Geneva: World Health Organisation (WHO)Syafriyudin dan Ledhe, N. 2015. Analisis pertumbuhan tanaman krisan pada variable warna cahaya lampu LED. Fakultas Teknologi Industri Institu Sains dan Teknologi AKPRIND YogyakartaE. H. Miller, "A note on reflector arrays (Periodical style-Accepted for publication)," IEEE Trans. Antennas Propagat., dipublikasikan.

[3] Masduqi, A. dan Abdu F. Assomadi. 2012. Operasi dan proses pengolahan air. Surabaya: IT S Press

[4] Rahmayanti, S. 2012. Analisis Penggunaan Downflow Slow Sand Filter untuk Pengolahan Air Sumur untuk Menjadi Air Minum dengan Variasi Ketebalan Media dan Kecepatan Filtrasi. Tugas Akhir Jurusan Teknik Lingkungan ITS: Surabaya.C. J. Kaufman, Rocky Mountain Research Lab., Boulder, CO, komunikasi pribadi, (1995, May).

[5] Fauziah, R. 2013. Penyediaan Air Minum untuk Masyarakat di Bantaran Kalimas Surabaya. Surabaya: ITS PressM. Young, The Techincal Writers Handbook. Mill Valley, CA: University Science (1989).

[6] Trihadiningrum, Y. 2012. Mikrobiologi Lingkungan. Surabaya: IT S Press

[7] Peraturan Menteri Kesehatan Republik Indonesia Nomor 492/MENKES/PER/IV/2010 